Images in...

\title{
Fetoscopic imaging of isolated cleft lip
}

\author{
Léonardo Gucciardo,' Tim Van Mieghem, ${ }^{1}$ Pierre Bernard, ${ }^{2}$ Jan Deprest ${ }^{1}$
}

${ }^{1}$ Department of Obstetrics and Gynecology, Fetal Therapy Unit, University Hospitals Leuven, Leuven, Belgium

${ }^{2}$ Department of Obstetrics, Cliniques Universitaires St-Luc, Brussels, Belgium

Correspondence to Jan Deprest, jan.deprest@uzleuven.be

\section{DESCRIPTION}

A 32-year-old woman, 22 weeks pregnant of monochorionic diamniotic twins, underwent fetoscopic laser coagulation of placental vascular anastomoses for a twin-to-twin transfusion syndrome (TTTS) Quintero stage III. Preoperative two- and three-dimensional ultrasound revealed the presence of an isolated unilateral cleft lip in the recipient twin (figure 1). At the time of surgery, fetoscopic inspection of the upper lip confirmed the unilateral cleft and the intact raphe of the palate (figure 2, video 1). The postoperative course was favourable and the patient delivered at 36 weeks of gestation. The cleft lip was surgically repaired soon after birth. Now aged one, both twins do fine and the remnants of the cleft can hardly be seen (figure 3).
Anomalies of the midline structures occur more often in monochorionic twins than in singletons, probably due to the zygotic clefting. In $6 \%$ of cases this malformation is discordant. ${ }^{1}$ As shown here, the prognosis of an isolated cleft lip is generally good and should therefore not influence the treatment of TTTS. ${ }^{2}$ We used the fetoscopic laser coagulation as an opportunity to visualise the recipient fetus directly and to confirm the morphological anomaly. Historically, embryoscopy has also been used by others as a complementary tool to assess birth defects early in pregnancy. ${ }^{3}$ However, this had high complication rates and was abandoned for the assessment of clefts, especially since (3D) ultrasound allows adequate description of fetal lip and palate. Animal experiments are now ongoing to assess the role of fetoscopy in the prenatal therapy of facial clefts. ${ }^{4}$

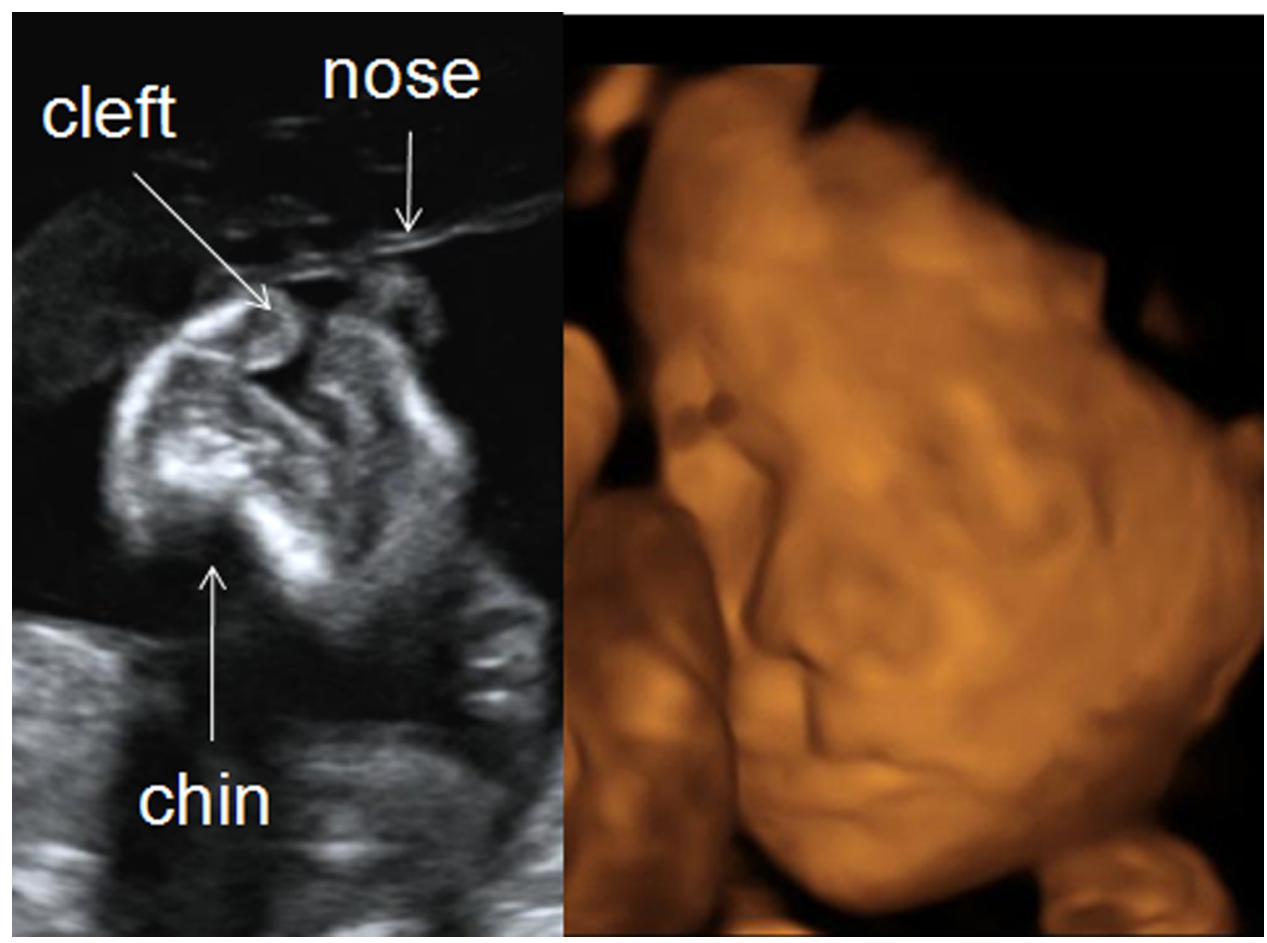

Figure 1 Two dimensional (left) and three dimensional (right) ultrasound image of fetal cleft lip. 


\section{BMJ Case Reports}

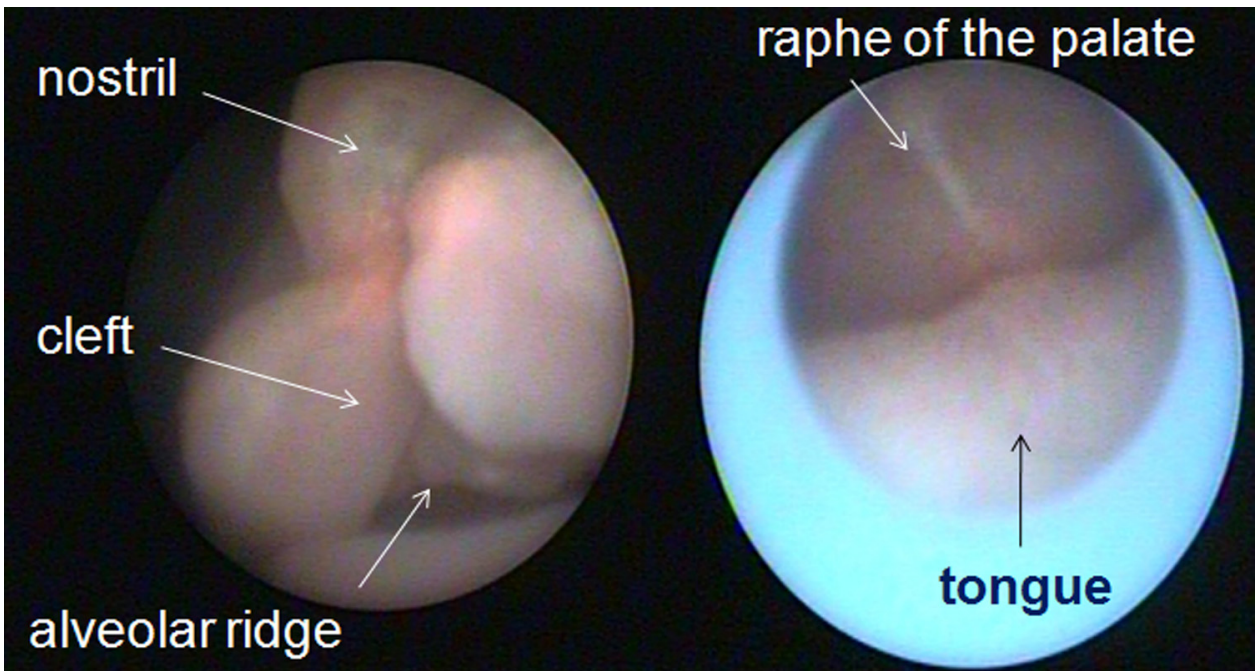

Figure 2 Fetoscopic image of cleft lip (left) and intact palate (right).

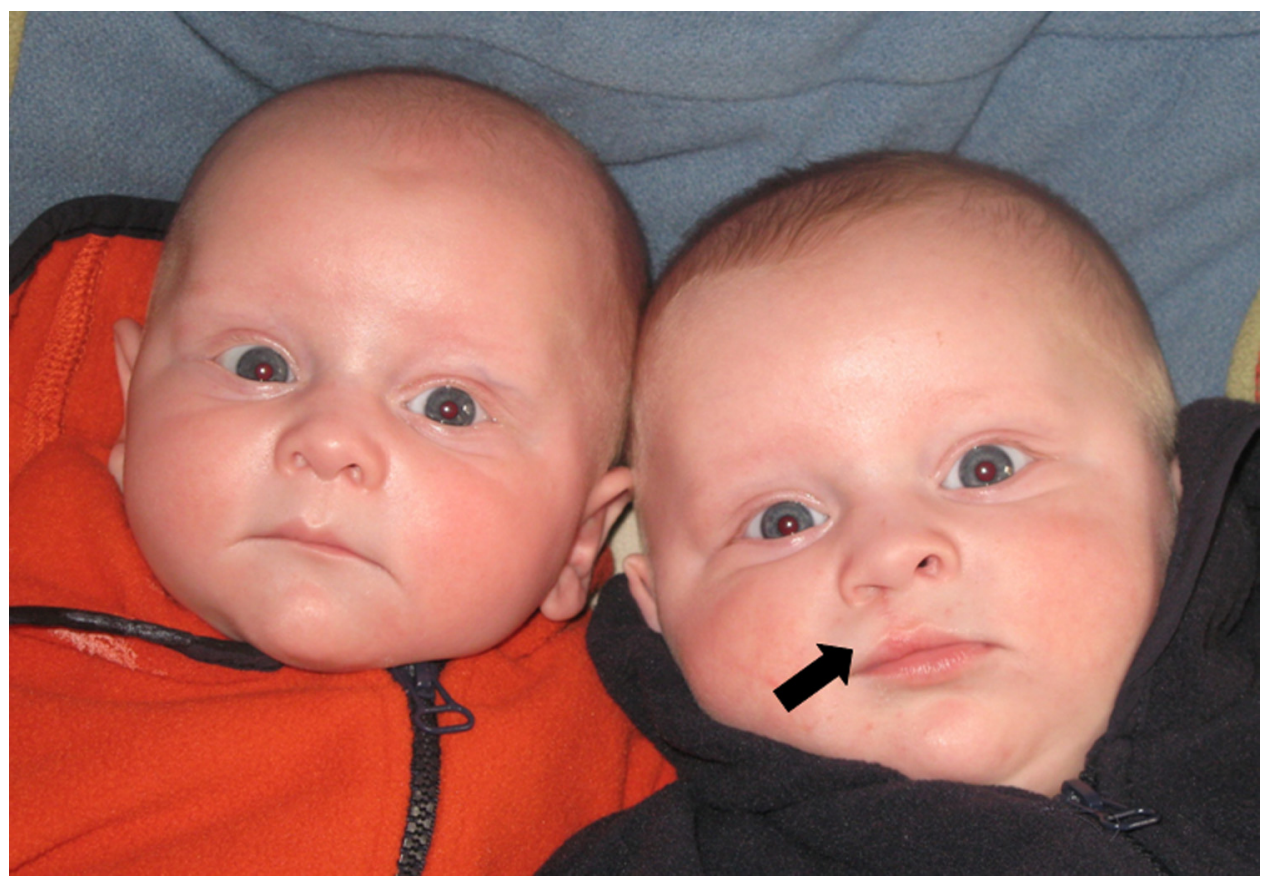

Figure 3 Postnatal image after surgical reconstruction of the lip. The scar in the affected twin (arrow) can only hardly be visualised.

Video 1 Fetoscopic investigation of a cleft lip. 10.1136/ bcr.10.2008.1079v1

\section{Competing interests None.}

Patient consent Obtained

\section{REFERENCES}

1. Lewi L, Jani J, Blickstein I, et al. The outcome of monochorionic diamniotic twin gestations in the era of invasive fetal therapy: a prospective cohort study. Am J Obstet Gynecol 2008;199:514.e1-8.
2. Mulliken JB. The changing faces of children with cleft lip and palate. N Engl J Med 2004;351:745-7.

3. Ville Y, Khalil A, Homphray T, et al. Diagnostic embryoscopy and fetoscopy in the first trimester of pregnancy. Prenat Diagn 1997;17:1237-46.

4. Wenghoefer MH, Deprest J, Goetz W, et al. Prenatal cleft lip and maxillary alveolar defect repair in a 2-step fetal lamb model. J Oral Maxillofac Surg 2007;65:2479-86. 


\section{BMJ Case Reports}

This pdf has been created automatically from the final edited text and images.

Copyright 2010 BMJ Publishing Group. All rights reserved. For permission to reuse any of this content visit http://group.bmj.com/group/rights-licensing/permissions.

BMJ Case Report Fellows may re-use this article for personal use and teaching without any further permission.

Please cite this article as follows (you will need to access the article online to obtain the date of publication).

Léonardo G, Van Mieghem T, Bernard P, Deprest J. Fetoscopic imaging of isolated cleft lip. BMJ Case Reports 2010;10.1136/bcr.10.2008.1079, date of publication

Become a Fellow of BMJ Case Reports today and you can:

- Submit as many cases as you like

- Enjoy fast sympathetic peer review and rapid publication of accepted articles

Access all the published articles

- Re-use any of the published material for personal use and teaching without further permission

For information on Institutional Fellowships contact consortiasales@bmjgroup.com

Visit casereports.bmj.com for more articles like this and to become a Fellow 